\title{
IDENTIFIKASI JENIS KAYU BERDASARKAN FITUR TEKSTUR MENGGUNAKAN LOCAL BINARY PATTERN (LBP) DENGAN METODE LEARNING VECTOR QUANTIZATION (LVQ)
}

\author{
Ni Made Yeni Dwi Rahayu ${ }^{1}$, Made Windu Antara Kesiman², I Gede Aris Gunadi ${ }^{3}$ \\ ${ }^{1,2,3}$ Program Studi Ilmu Komputer, Pascasarjana, Universitas Pendidikan Ganesha \\ Singaraja, Bali
}

e-mail: yeni.brt@gmail.com ${ }^{1}$, antara.kesiman@undiksha.ac.id ${ }^{2}$, igedearisgunadi@undiksha.ac.id ${ }^{3}$

\begin{abstract}
Abstrak
Pada umumnya pengenalan jenis kayu masih dilakukan dengan menggunakan indera penglihatan dan penciuman. Hal tersebut dapat mempengaruhi proses jual beli dimana waktu yang dibutuhkan untuk pengenalan kayu menjadi lebih lama sehingga menyebabkan proses bisnis menjadi kurang efektif. Penelitian ini bertujuan untuk membangun suatu model machine learning untuk proses identifikasi jenis kayu berdasarkan fitur teksur citra pada kayu. Metode Local Binary Pattern (LBP) digunakan dalam proses ekstraksi ciri untuk menghasilkan vektor ciri yang dijadikan data input pada proses klasifikasi citra dengan menggunakan metode Learning Vector Quantization (LVQ). Parameter yang digunakan pada metode LBP meliputi numpoint dan radius dengan nilai 1 sampai 10 . Hasil penelitian dari metode ini didapatkan akurasi tertinggi $68,33 \%$ pada numpoint 2 dan radius 1 . Hasil pengujian yang cukup rendah dapat dipengaruhi oleh beberapa faktor yaitu jumlah citra latih dan terdapat beberapa citra kayu memiliki pola yang hampir sama.
\end{abstract}

Kata kunci: kayu, local binery pattern, learning vector quantization.

\section{Abstract}

In general, the introduction of wood species is still done by using the senses of sight and smell. This can affect the buying and selling process where the time required for the introduction of wood becomes longer, causing the business process to be less effective. This study aims to build a model machine learning for the identification process of wood species based on the texture features of the image on the wood. The Local Binary Pattern (LBP) method is used in the feature extraction process to produce vectors feature that are used as input data in the image classification process using the method Learning Vector Quantization (LVQ). The parameters used in the LBP method include numpoint and radius with a value of 1 to 10. The results of this study obtained the highest accuracy of $68.33 \%$ on numpoint 2 and radius 1. The test results are quite low can be influenced by several factors, namely the number of training images and there are several wood images that have almost the same pattern.

Keywords : wood, local binery pattern, learning vector quantization

Diterima Redaksi: 31-10-2021 | Selesai Revisi: 5-12-2021 | Diterbitkan Online: 31-12-2021 DOI: https://doi.org/10.23887/janapati.v10i3.40804

\section{PENDAHULUAN}

Pengenalan jenis kayu umumnya dapat dilakukan dengan melakukan pengamatan berdasarkan pada ciri-ciri tertentu. Ciri-ciri umum dalam proses pengamatan jenis kayi diantaranya bisa dikenali secara langsung oleh panca indera (bau, warna, corak, tekstur, arah serat) maupun ciri anatomi yang hanya dapat diamati secara jelas dengan menggunakan alat seperti kaca pembesar atau mikroskop [1].

Dalam melakukan klasifikasi jenis kayu tentunya mudah bagi manusia yang mengerti akan karakteristik tumbuhan kayu tersebut.
Tetapi pengetahuan mengenai klasifikasi kayu didapatkan dengan latihan terus menerus, berulang-ulang dan waktu yang lama. Permasalahan yang sering terjadi di dalam keseharian adalah apabila seorang penjual yang melakukan identifikasi kayu belum terampil, maka akan mempengaruhi dalam proses jual beli dimana waktu yang dibutuhkan untuk pengenalan kayu menjadi lebih lama sehingga proses bisnis menjadi tidak efektif [2].

Berbagai penelitian tentang pengenalan pola citra sudah banyak diterapkan dengan bermacam bentuk aplikasi dan algoritma. Salah 
satu komponen dasar pembentuk citra yaitu tekstur, dapat digunakan sebagai teknik untuk pengenalan citra. Hal yang dapat dibedakan dari tekstur citra diantaranya keseragaman, kerapatan, kekasaran dan keteraturan. Pada sistem komputerisasi digunakan analisis tekstur untuk mengetahui pola citra digital dari ciri yang didapat secara matematis [3].

Salah satu metode untuk ekstraksi fitur tekstur yang cukup handal adalah Local Binary Pattern (LBP), karena LBP memiliki kelebihan dapat mendeskripsikan karakterirstik tekstur pada permukaan. Penelitian mengenai identifikasi kayu sebelumnya pernah dilakukan oleh Canggih Trisyanto [4] yang menggunakan metode Local Binary Pattern dan klasifikasi citra Probabilistic Neural Network untuk identifikasi kayu ramin. Penelitiannya menghasilkan nilai rata-rata akurasi yaitu sebesar 79,77 \%. Faisal Nur Achsani [5] melakukan penelitian untuk mendeteksi adanya cacat pada kayu menggunakan metode ekstraksi ciri Local Binary Pattern dan klasifikasi citra menggunakan metode $K$ Nearest Neighbor (KNN) dengan tingkat akurasi $89,4 \%$. Sedangkan metode klasifikasi yang terkait dengan identifikasi kayu pernah dilakukan oleh Ahmad Yasir Fikri [6]. Dalam penelitian identifikasi jenis kayu tersebut menggunakan metode klasifikasi Learning Vector Quantization (LVQ) berdasarkan ekstraksi fitur Gray Level Co-Occurrence Matrix (GLCM). Hasil dari metode yang digunakan menghasilkan akurasi sebesar $78,4 \%$.

Sistem klasifikasi Learning Vector Quantization (LVQ) memiliki kemampuan sangat fleksibel dan dapat diterapkan dalam masalah multi-kelas secara langsung [7]. Kelebihan lain dari sistem Learning Vector Quantization (LVQ) adalah memiliki kemampuan yang lebih baik dalam hal mengenali (mengklasifikasikan) citra dibandingkan algoritma Backpropragation dan metode Cascade Forward [8]. Perbandingan metode Backpropragation dan Learning Vector Quantization (LVQ) pernah dilakukan untuk pengenalan wajah [9] mendapatkan metode Learning Vector Quantization (LVQ) mendapatkan hasil lebih baik dari segi akurasi waktu. Begitu juga dalam penelitian Nagare [10] membandingkan metode Backpropragation dengan Learning Vector Quantization (LVQ) dalam pengenalan karakter menyimpulkan pengenalan karakter menggunakan LVQ mendapatkan nilai akurasi lebih baik dibandingkan Backpropagation yaitu LVQ dengan nilai akurasi $94,44 \%$ dan BackPropagation dengan nilai akurasi $66,67 \%$.

Berdasarkan kelebihan yang dimiliki oleh LBP dan LVQ, maka penulis akan melakukan penelitian untuk mengidentifikasi kayu dengan metode ekstraksi fitur tekstur dengan Local Binary Pattern (LBP) dan metode klasifikasi Learning Vector Quantization (LVQ). Tujuan dari penelitian ini adalah membangun suatu model machine laearning agar dapat mengindentifikasi kayu dengan lebih akurat. Melalui metode ini, citra masukan yang belum diketahui akan dicari kesamaannya dengan sekumpulan citra yang disebut sebagai citra template. Keuntungan metode ini adalah semua piksel akan terklasifikasi, dan merupakan metode yang paling cepat secara komputasi. Melalui sistem identifikasi kayu berbasis citra ini diharapkan dapat membantu manusia dalam identifikasi beberapa jenis kayu secara cepat dan akurat. Jenis kayu yang digunakan pada penelitian ini yaitu kayu bangkirai, jati, dan mahoni.

\section{METODE}

Tahapan pada penelitian ini terdiri dari studi pustaka, perancangan sistem, pengumpulan data, pengolahan data dan pengujian.

\section{a. Perancangan Sistem}

Pada Gambar 1 dapat dilihat perancangan penelitian sistem identifikasi kayu yang meliputi beberapa proses. Proses pertama pengumpulan data set yang meliputi proses pengambilan data citra berupa citra kayu RGB yang akan digunakan sebagai data latih dan data uji. Selanjutnya terdapat dua proses utama yaitu proses pelatihan dan proses pengenalan (pengujian). Pada proses pelatihan dan pengujian terdapat dua tahapan proses yang sama yaitu preprocessing dan ekstraksi fitur dengan Local Binary Pattern (LBP). Dalam proses pelatihan setelah tahap ekstraksi fitur selesai selanjutkan dilakukan klasifikasi dengan metode Learning Vector Quantization (LVQ) dan dilanjutkan dengan proses pengenalan (pengujian) dengan menggunakan bobot akhir dari hasil proses pelatihan untuk mengidentifikasi jenis jenis kayu. 


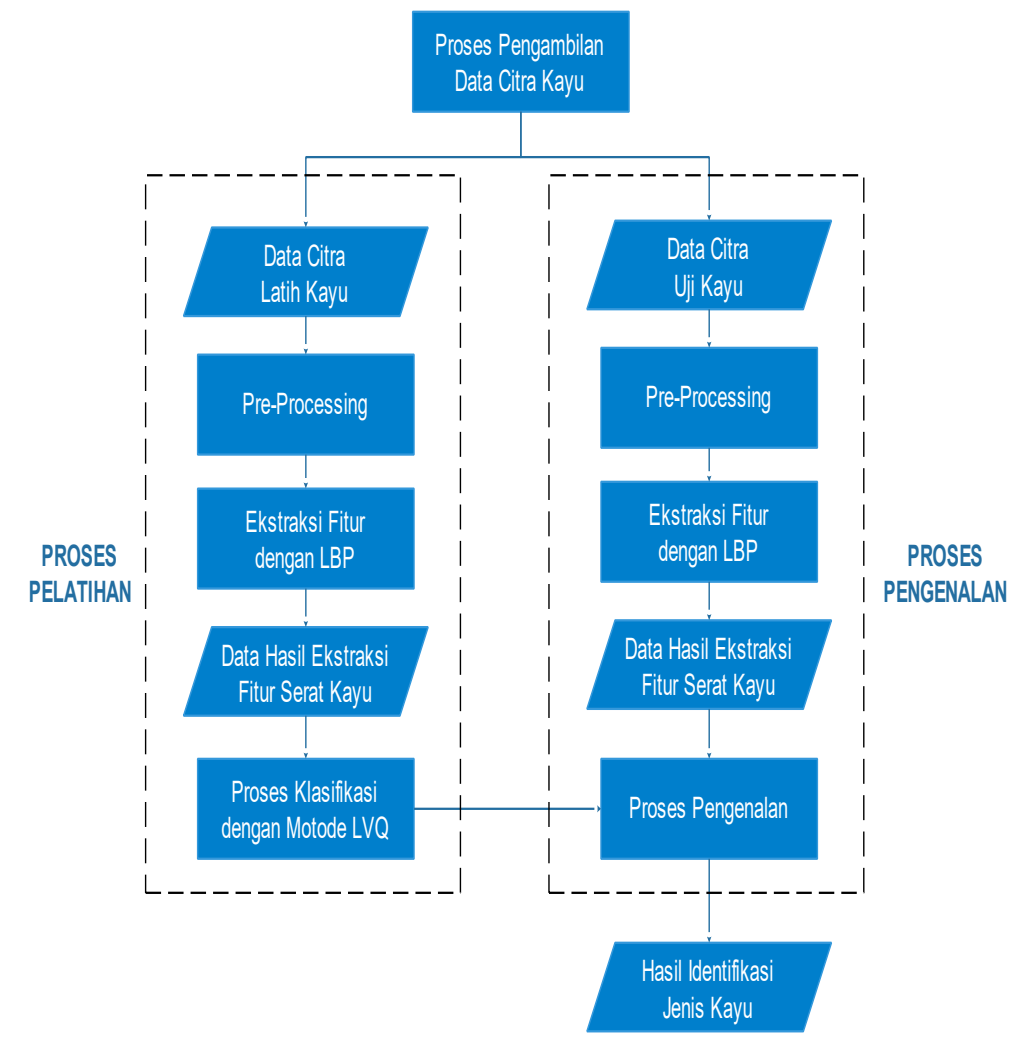

Gambar 1. Alur Rancangan Penelitian

b. Metode Pengumpulan Data

Pada proses pengambilan data citra kayu dilakukan dengan cara mengambil citra mikroskopis kayu/citra pori kayu. Jenis kayu yang digunakan pada penelitian ini yaitu kayu bangkirai, jati, dan mahoni. Proses pengambilan data citra kayu meliputi proses sebagai berikut.

1) Pemotongan Kayu

Proses pemotongan kayu pada Gambar 2 dilakukan dengan cara memotong bidang kayu secara tegak lurus dengan arah pertumbuhan pohon atau bidang penampang kayu dengan tujuan untuk mendapatkan bagian pori kayu (bidang cross section).

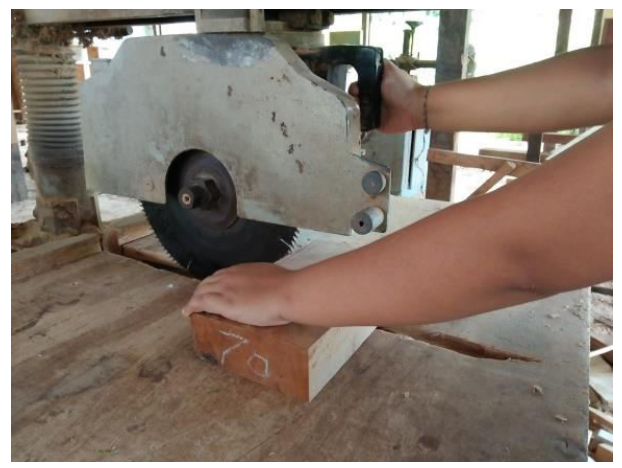

Gambar 2. Proses Pemotongan Bagian Penampang Kayu
2) Pemindaian Kayu

Kayu yang sudah dipotong pada bagian penampang, selanjutnya diletakkan di bawah alat pindai berupa kamera mikroskop digital (Gambar 3). Hasil pemindaian citra kayu adalah gambar digital berupa citra RGB dengan format jpg (.jpg) berukuran 640x480.

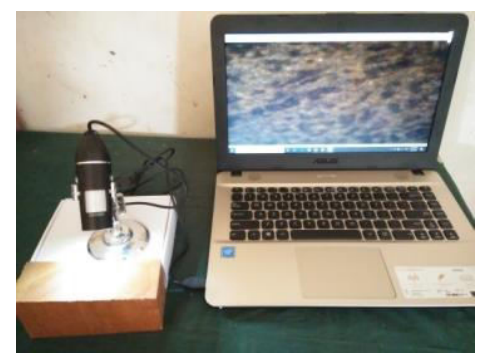

Gambar 3. Proses Pemindaian Citra Kayu

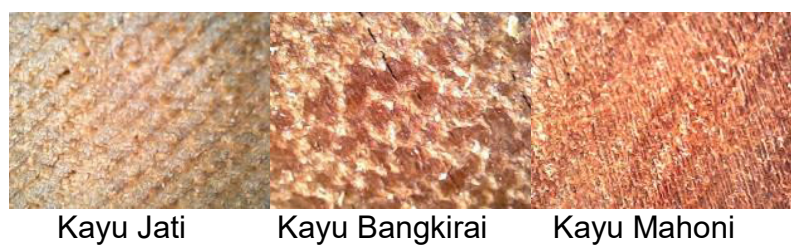

Gambar 4. Data Citra Hasil Pemindaian dengan Mikroskop Digital 
c. Metode Pengolahan Data

Proses pengolahan data citra kayu dilakukan dengan beberapa tahap diantaranya:

1) Tahap Akusisi Citra

Tahap akuisis citra dapat dilihat pada Gambar 4.

2) Tahap Preprocessing

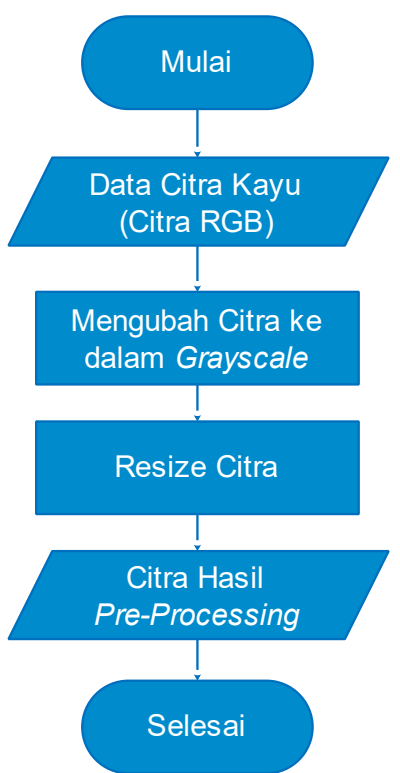

Gambar 5. Alur Proses Preprocessing

Tujuan dari preprocessing (pengolah awal) adalah untuk mendapatkan informasi dari citra secara optimal [11], untuk meningkatkan kualitas citra sehingga bagian-bagian citra terbaca dengan benar oleh sistem [12] dan mengurangi waktu pemrosesan data [4]. Tahap preprocessing meliputi resize dan grayscaling. Pada tahap resize dilakukan pengubahan ukuran pada citra dengan tujuan untuk menyeragamkan ukuran input citra dan memperkecil ukuran citra sehingga proses komputasi menjadi lebih cepat [11]. Ukuran dimensi citra kayu dirubah dari 640x480 menjadi 128x128. Tahap preprocessing berikutnya adalah grayscaling yaitu proses merubah citra input RGB menjadi grayscale. Tujuan dari tahap grayscaling adalah untuk normalisasi warna piksel pada citra sehingga dapat menghasilkan ciri yang lebih baik pada proses pemisahan ciri [13]. Hasil dari proses preprocessing adalah citra kayu dengan aras keabuan yang sudah siap untuk proses ekstraksi ciri. Gambar 5 merupakan tampilan dari tahap preprocessing.

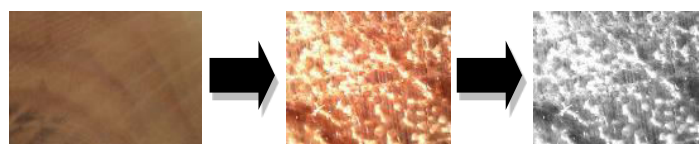

Gambar 6. Tahap Preprocessing
3) Tahap Ekstraksi Fitur

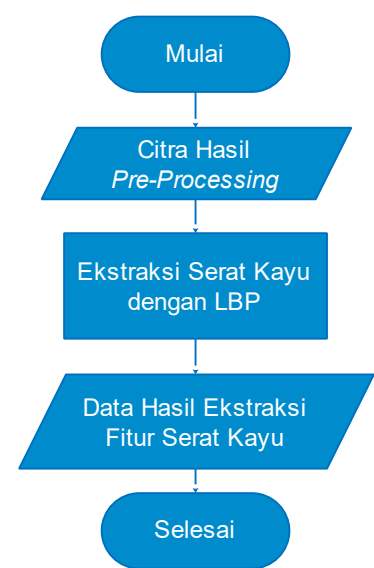

Gambar 7. Proses Ekstraksi Fitur Pelatihan

Ekstraksi fitur merupakan proses pengambilan ciri atau fitur dari suatu objek atau bentuk pada citra yang akan dibedakan atau dikenali dengan objek lainnya. Pada tahapan ini proses yang dilakukan adalah mengekstraksi data (citra kayu) dari preprocessing dengan metode LBP.

Local Binary Pattern (LBP) merupakan metode yang dipakai untuk ukuran tekstur grayscale yang telah terbukti efektif dan invariant terhadap pencahayaan yang berbeda [14]. Mäenpää menjelaskan penggunaan LBP dapat dipakai untuk mencari pola-pola tekstur lokal pada citra. Nilai LBP didapatkan dengan melakukan thresholding pada piksel-piksel tetangga yang berbentuk circular dengan menggunakan piksel pusat, kemudian mengalikannya dengan pembobotan biner. LBP bekerja dengan delapan piksel tetangga yang tersebar melingkar (circular neighborhoods), dengan pusat piksel berada di tengah dan menggunakan nilai piksel pusatnya sebagai threshold. Nilai threshold didapat dengan cara memberikan label pada setiap piksel tetangga diantara nilai tengah piksel. Jika nilai tetangga lebih kecil dari nilai pusat piksel maka nilai perbandingannya 0 , jika nilai tetangga lebih besar dari nilai pusat piksel maka nilai perbandingannya 1. Secara matematis thresholding dihitung dengan persamaan (1).

$$
\begin{aligned}
& L B P_{p, r}=\left(x_{c}, y\right)=\sum_{p=0}^{p-1} S\left(g_{p}-g_{c}\right) 2^{p} \\
& s(x) \begin{cases}1, & x \geq 0 \\
0, & x<0\end{cases}
\end{aligned}
$$

Keterangan:

$$
\begin{array}{ll}
\mathrm{P} & \text { : banyaknya piksel tetangga } \\
\mathrm{R} & \text { : nilai radius/jarak } \\
\mathrm{gc} & \text { : nilai dari piksel } \mathrm{x} \text { dan y (piksel pusat) }
\end{array}
$$


gp : nilai piksel tetangga

Threshold

\begin{tabular}{|l|l|l|}
\hline 5 & 9 & 1 \\
\hline 4 & 4 & 6 \\
\hline 7 & 2 & 3 \\
\hline
\end{tabular}

$\Rightarrow$\begin{tabular}{|l|l|l|}
\hline 1 & 1 & 0 \\
\hline 1 & & 1 \\
\hline 1 & 0 & 0 \\
\hline
\end{tabular}

Bobot

$\mathrm{xc}, \mathrm{yc} \quad$ : koordinat pusat

\begin{tabular}{|l|l|l|}
\hline $2^{0}$ & $2^{1}$ & $2^{2}$ \\
\hline $2^{7}$ & & $2^{3}$ \\
\hline $2^{6}$ & $2^{5}$ & $2^{4}$ \\
\hline
\end{tabular}

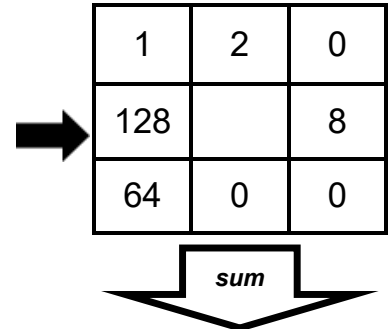

Nilai Desimal LBP : $1+2+0+8+0+0+64+128=203$

Gambar 8. Menentukan Nilai Threshold dan Bobot LBP

Pada proses ekstraksi fitur dengan metode LBP menghasilkan dimensi citra kayu 1 × 100 piksel. Gambar 4. 4, 4. 5, 4. 6 merupakan tampilan perubahan gambar dari citra input ke grayscale dan hasil ekstraksi dengan metode LBP. Parameter yang digunakan dalam proses ekstraksi adalah numpoint dan radius.

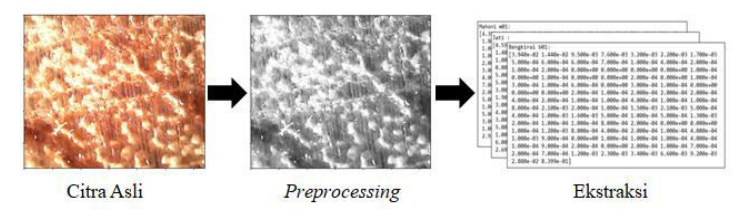

Gambar 9. Hasil Tahap Ekstraksi Fitur

4) Tahap Klasifikasi

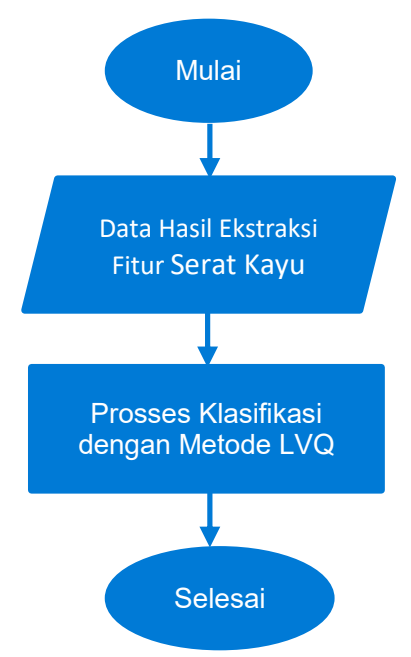

Gambar 10. Proses Klasifikasi Pelatihan

Pada penelitian ini proses klasifikasi menggunakan metode dengan Learning Vector Quantization. Learning Vector Quantization (LVQ) mengklasifikasikan input secara berkelompok ke dalam kelas yang sudah didefinisikan melalui jaringan yang telah dilatih. Tujuan dari LVQ adalah untuk mendekati distribusi kelas vektor untuk meminimalkan kesalahan dalam pengklasifikasian. Arsitektur LVQ ini terdiri dari input, lapisan kohonen dan lapisan output [10].

Langkah-langkah perhitungan algoritma LVQ sebagai berikut:

a. Langkah 0: Inisialisasi

Tetapkan Bobot Awal (W), Maksimum Epoch (MaxEpoch), dan Learning rate ( $\alpha$ ).

b. Langkah 1: Jika kondisi stop salah, lakukan langkah 2-6

c. Langkah 2: Untuk setiap training vector, lakukan langkah 3-4

d. Langkah 3: Dapatkan nilai j sehingga $\| x-$ wj|l bernilai minimum

e. Langkah 4: Update nilai bobot wj Jika $\mathrm{T}=\mathrm{Cj}$

$\mathrm{Wj}($ baru $)=\mathrm{wj}($ lama $)+\alpha(x-w j($ lama $))$

Jika $T \neq C \mathrm{j}$

$\mathrm{Wj}($ baru $)=\mathrm{wj}($ lama $)-\alpha(\mathrm{x}-\mathrm{wj}($ lama $))$

f. Langkah 5: Update nilai learning rate

g. Langkah 6: Uji kondisi stop

Uji kondisi stop ini dapat dilakukan berdasarkan jumlah iterasi tertentu (mulai dari langkah 1) atau setelah laju pembelajaran yang telah mencapai nilai yang sangat kecil. Untuk mencapai nilai yang sangat kecil diperlukan perhitungan terus menerus sehingga membutuhkan keperluan memori yang sangat besar. Untuk itu, dalam perhitungan LVQ bisa ditentukan maksimal perulangan (epoch).

Dimana:

$$
\begin{aligned}
\mathrm{X}= & \text { training vector }(\mathrm{x} 1, \ldots, \mathrm{xi}, \ldots, \mathrm{xn}) \\
\mathrm{T}= & \text { kategori training vector yang benar } \\
& \text { untuk pelatihan } \\
\mathrm{Wj}= & \text { vektor bobot untuk unit keluaran } \\
& \mathrm{ke-j}(\mathrm{w} 1 \mathrm{j}, \ldots, \ldots, \mathrm{wij}, \ldots ., \mathrm{win})
\end{aligned}
$$


Cj = kategori atau kelas yang diwakili oleh nilai unit keluaran ke-j (hasil training)

\|x-wj $\|=$ euclidian distances antara vektor masukkan dan vektor bobot dari unit keluaran ke-j.

Proses klasifikasi dibagi dalam dua tahap, yaitu tahap pelatihan dan pengenalan. Pada tahap pelatihan atau training ini citra data set kayu akan dilatih agar dapat mengenali jenis citra kayu berdasarkan fitur yang telah diekstraksi menggunakan metode Local Binary Pattern. Citra kayu yang digunakan dalam proses pelatihan (data latih) ini berjumlah 240 citra yang dibagi menjadi tiga kelompok citra yaitu citra bangkirai, jati dan mahoni dengan masing-masing data latih kayu berjumlah 80 citra.

Dalam proses pelatihan dengan metode Learning Vector Quantization ini dimulai dengan melakukan normalisasi nilai Local Binary Pattern dari data set citra kayu, menentukan nilai learning rate (alpha), max epoch dan epoch untuk proses pembelajarannya. Selanjutnya menghitung best matching unit (BMU) dengan menghitung jarak antara vektor acuan (codebook) dengan normalisasi tiap data set citra kayu (vektor input), kemudian akan dicari jarak terdekat antara vektor acuan dengan vektor input dengan euclidean distances. Hasil dari klasifikasi dengan Learning Vector Quantization adalah nilai terdekat dari kelas data uji citra kayu yang dituju. Dalam klasifikasi ini kelas ada tiga yaitu kelas jati, bangkirai dan mahoni.

Tahap kedua proses klasifikasi adalah pengenalan atau testing. Dalam tahap pengenalan ini citra kayu akan diuji coba dengan model yang telah dibuat dalam proses pelatihan. Citra yang digunakan dalam tahap pengenalan ini menggunakan citra kayu yang berbeda dengan tahap pelatihan, sehingga performance dari akurasi model Learning Vector Quantization bisa diukur keakuratannya. Citra kayu yang digunakan dalam proses pengenalan (data uji) berjumlah 60 citra yang dibagi menjadi tiga kelompok citra yaitu citra bangkirai, jati dan mahoni dengan masing-masing data uji kayu berjumlah 20 citra.

5) Tahap Pelatihan

Pada proses pelatihan dengan metode LVQ menggunakan parameter learning rate 0,1 dan epoch 100. Penggunaan learning rate 0,1 diharapkan dapat memberikan pembelajaran yang stabil [15] dan pemilihan epoch 100 didasarkan pada jumlah rasio data set 80:20 yang digunakan sebagai data uji dan pelatihan berpengaruh dalam meningkatkan akurasi [16]. Pada proses klasifikasi dengan metode LVQ didapatkan nilai bobot (codebook) data latih yang akan digunakan untuk tahap pengujian.

6) Tahap Pengujian

Pengujian performa sistem klasifikasi menjelaskan seberapa baik sebuah sistem dalam mengklasifikasikan data. Dalam klasifikasi Learning Vector Quantization pada penelitian ini, pengujian performa menggunakan confusion matrix atau disebut juga dengan error matrix. Pada dasarnya confusion matrix memberikan informasi perbandingan hasil klasifikasi yang dilakukan oleh sistem (model) dengan hasil klasifikasi sebenarnya. Confusion matrix berbentuk tabel matriks yang menggambarkan kinerja model klasifikasi pada serangkaian data uji yang nilai sebenarnya diketahui. Terdapat empat istilah sebagai representasi hasil proses klasifikasi pada confusion matrix yang dapat dilihat pada Gambar 10

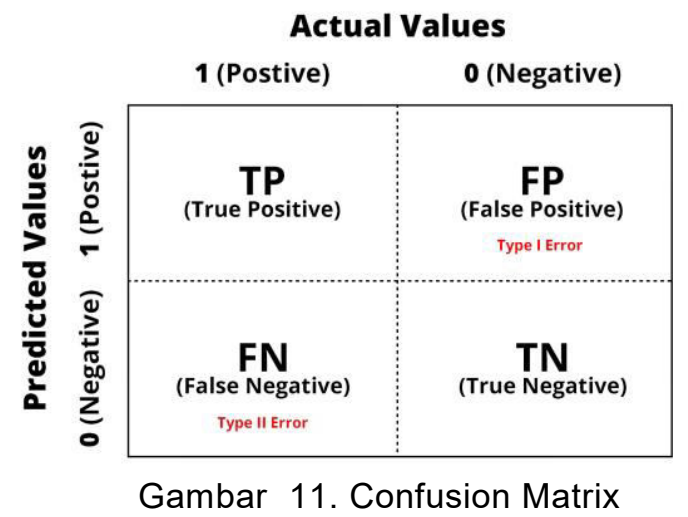

Keterangan:

a. True Positive (TP): data citra kayu positif yang diprediksi benar.

b. True Negative (TN): data citra kayu negatif yang diprediksi dengan benar

c. False Positive (FP): data citra kayu negatif tetapi diprediksi sebagai data positif.

d. False Negative (FN): data citra kayu positif tetapi diprediksi sebagai data negatif.

Berdasarkan keempat bagian nilai pada Gambar 10 (TN, FP, TP, dan FN) didapatkan nilai akurasi, presisi dan recall yang dihitung dengan persamaan (3) (4) (5).

$$
\begin{aligned}
& \text { Akurasi }=\frac{T P+T N}{T P+T N+F P+F N} \times 100 \% \\
& \text { Pr esisi }=\frac{T P}{T P+F P} \times 100 \%
\end{aligned}
$$


Re call $=\frac{T P}{T P+F N} x 100 \%$

Data set yang digunakan dalam tahap pengujian menggunakan citra kayu yang berbeda dengan tahap pelatihan, sehingga performance dari akurasi model Learning Vector Quantization bisa diukur keakuratannya. Data set yang digunakan sebagai data uji berjumlah 60 citra. Pada proses klasifikasi dengan metode LVQ parameter yang digunakan yaitu learning rate 0,1 dan epoch 100 .

\section{HASIL DAN PEMBAHASAN}

Dalam penelitian ini dilakukan pengujian terhadap metode LBP LVQ dan metode LBP normalisasi LVQ. Perbedaan pada pengujian metode LBP LVQ dan metode LBP normalisasi LVQ ada pada proses normalisasi. Pada metode LBP normalisasi LVQ, data set citra kayu yang telah diekstraksi dengan LBP akan dinormalisasi sebelum menuju proses klasifikasi. Sedangkan pada metode LBP LVQ, tidak terdapat proses normalisasi setelah proses ekstrasi, melainkan langsung menuju ke proses klasifikasi. Pada kedua metode tersebut akan dilakukan pengujian studi empiris terhadap pengaruh nilai parameter pada LBP yaitu radius (nilai jarak) dan numpoint (jumlah tetangga) dengan rentang nilai 1 sampai 10 .

Tabel 1. Hasil Pengujian Parameter

\begin{tabular}{|c|c|c|c|}
\hline \multicolumn{2}{|c|}{ Parameter } & \multirow{2}{*}{\multicolumn{2}{|c|}{$\begin{array}{l}\text { Akurasi } \\
\text { Metode }\end{array}$}} \\
\hline \multirow{2}{*}{ Numpoint } & \multirow{2}{*}{ Radius } & & \\
\hline & & LBP+LVQ & LBP+Normalisasi+LVQ \\
\hline 1 & \multirow{10}{*}{1} & 0,333 & 0,300 \\
\hline 2 & & 0,683 & 0,333 \\
\hline 3 & & 0,617 & 0,333 \\
\hline 4 & & 0,650 & 0,233 \\
\hline 5 & & 0,333 & 0,250 \\
\hline 6 & & 0,617 & 0,333 \\
\hline 7 & & 0,650 & 0,333 \\
\hline 8 & & 0,650 & 0,333 \\
\hline 9 & & 0,650 & 0,333 \\
\hline 10 & & 0,600 & 0,333 \\
\hline 1 & \multirow{10}{*}{2} & 0,583 & 0,283 \\
\hline 2 & & 0,633 & 0,333 \\
\hline 3 & & 0,583 & 0,317 \\
\hline 4 & & 0,617 & 0,400 \\
\hline 5 & & 0,417 & 0,333 \\
\hline 6 & & 0,583 & 0,333 \\
\hline 7 & & 0,400 & 0,333 \\
\hline 8 & & 0,533 & 0,317 \\
\hline 9 & & 0,367 & 0,383 \\
\hline 10 & & 0,417 & 0,333 \\
\hline 1 & \multirow{10}{*}{3} & 0,200 & 0,283 \\
\hline 2 & & 0,683 & 0,333 \\
\hline 3 & & 0,450 & 0,283 \\
\hline 4 & & 0,483 & 0,333 \\
\hline 5 & & 0,450 & 0,350 \\
\hline 6 & & 0,483 & 0,483 \\
\hline 7 & & 0,367 & 0,467 \\
\hline 8 & & 0,450 & 0,550 \\
\hline 9 & & 0,417 & 0,333 \\
\hline 10 & & 0,433 & 0,367 \\
\hline 1 & \multirow{4}{*}{4} & 0,267 & 0,300 \\
\hline 2 & & 0,617 & 0,333 \\
\hline 3 & & 0,567 & 0,333 \\
\hline 4 & & 0,517 & 0,367 \\
\hline
\end{tabular}




\begin{tabular}{|c|c|c|c|}
\hline 5 & & 0,267 & 0,383 \\
\hline 6 & & 0,333 & 0,400 \\
\hline 7 & & 0,317 & 0,450 \\
\hline 8 & & 0,450 & 0,467 \\
\hline 9 & & 0,433 & 0,333 \\
\hline 10 & & 0,433 & 0,467 \\
\hline 1 & \multirow{10}{*}{5} & 0,200 & 0,383 \\
\hline 2 & & 0,450 & 0,333 \\
\hline 3 & & 0,433 & 0,333 \\
\hline 4 & & 0,500 & 0,450 \\
\hline 5 & & 0,283 & 0,350 \\
\hline 6 & & 0,283 & 0,350 \\
\hline 7 & & 0,367 & 0,450 \\
\hline 8 & & 0,400 & 0,350 \\
\hline 9 & & 0,367 & 0,450 \\
\hline 10 & & 0,417 & 0,383 \\
\hline 1 & \multirow{10}{*}{6} & 0,217 & 0,317 \\
\hline 2 & & 0,550 & 0,333 \\
\hline 3 & & 0,383 & 0,400 \\
\hline 4 & & 0,450 & 0,383 \\
\hline 5 & & 0,367 & 0,283 \\
\hline 6 & & 0,367 & 0,350 \\
\hline 7 & & 0,400 & 0,333 \\
\hline 8 & & 0,400 & 0,333 \\
\hline 9 & & 0,367 & 0,367 \\
\hline 10 & & 0,450 & 0,350 \\
\hline 1 & \multirow{10}{*}{7} & 0,233 & 0,333 \\
\hline 2 & & 0,500 & 0,333 \\
\hline 3 & & 0,383 & 0,350 \\
\hline 4 & & 0,467 & 0,350 \\
\hline 5 & & 0,400 & 0,300 \\
\hline 6 & & 0,333 & 0,333 \\
\hline 7 & & 0,433 & 0,350 \\
\hline 8 & & 0,467 & 0,350 \\
\hline 9 & & 0,383 & 0,350 \\
\hline 10 & & 0,417 & 0,333 \\
\hline 1 & \multirow{10}{*}{8} & 0,200 & 0,333 \\
\hline 2 & & 0,500 & 0,383 \\
\hline 3 & & 0,367 & 0,317 \\
\hline 4 & & 0,450 & 0,317 \\
\hline 5 & & 0,367 & 0,250 \\
\hline 6 & & 0,350 & 0,333 \\
\hline 7 & & 0,433 & 0,283 \\
\hline 8 & & 0,433 & 0,300 \\
\hline 9 & & 0,400 & 0,317 \\
\hline 10 & & 0,433 & 0,300 \\
\hline 1 & \multirow{6}{*}{9} & 0,183 & 0,317 \\
\hline 2 & & 0,467 & 0,383 \\
\hline 3 & & 0,367 & 0,350 \\
\hline 4 & & 0,483 & 0,317 \\
\hline 5 & & 0,467 & 0,317 \\
\hline 6 & & 0,417 & 0,267 \\
\hline
\end{tabular}




\begin{tabular}{|c|c|c|c|}
\hline 7 & & 0,450 & 0,250 \\
\hline 8 & & 0,483 & 0,250 \\
\hline 9 & & 0,450 & 0,267 \\
\hline 10 & & 0,500 & 0,283 \\
\hline 1 & \multirow{10}{*}{10} & 0,183 & 0,317 \\
\hline 2 & & 0,567 & 0,383 \\
\hline 3 & & 0,433 & 0,367 \\
\hline 4 & & 0,517 & 0,367 \\
\hline 5 & & 0,483 & 0,317 \\
\hline 6 & & 0,383 & 0,300 \\
\hline 7 & & 0,433 & 0,317 \\
\hline 8 & & 0,517 & 0,283 \\
\hline 9 & & 0,467 & 0,250 \\
\hline 10 & & 0,533 & 0,283 \\
\hline & & 0,4392 & 0,3408 \\
\hline
\end{tabular}

Tabel 1 merupakan hasil pengujian dengan menggunakan metode LBP LVQ dan metode LBP normalisasi LVQ. Pada Tabel 1 didapatkan akurasi paling besar yaitu $68,33 \%$ yang berada pada numpoint $=2$ dan radius $=$ 1.

Hasil pengujian dari Tabel 1 selanjutnya dilakukan klasifikasi citra kayu dengan membandingkan nilai prediksi benar dan salah berdasarkan nilai akurasi terbesar yang didapatkan pada metode LBP LVQ dan LBP normalisasi LVQ dengan jumlah citra uji masing-masing kayu sebanyak 20 citra (Tabel 2).

Pada Gambar 12 dilakukan perbandingan akurasi untuk tiap jenis jenis kayu dengan menggunakan metode LBP LVQ dan LBP normalisasi LVQ berdasarkan nilai akurasi tertinggi pada dua metode tersebut. Hasil dari perbandingan tersebut menunjukkan bahwa metode LBP LVQ lebih baik dalam mengenali tiap jenis jenis kayu dibandingkan dengan metode LBP normalisasi LVQ.

Tabel 2. Hasil Klasifikasi Citra Kayu Metode LBP LVQ

\begin{tabular}{llccc}
\hline \multirow{2}{*}{ Metode } & Jenis & \multicolumn{3}{c}{ Hasil Prediksi } \\
\cline { 3 - 5 } & kayu & Bangkirai & Jati & Mahoni \\
\hline \multirow{3}{*}{ LBP LVQ } & Bangkirai & 12 & 1 & 7 \\
& Jati & 0 & 20 & 0 \\
LBP & Mahoni & 3 & 8 & 9 \\
Normalis & Bangkirai & 18 & 0 & 2 \\
asi LVQ & Jati & 17 & 1 & 2 \\
\hline
\end{tabular}

\section{Perbandingan Akurasi Sampel Kayu}

(\%)

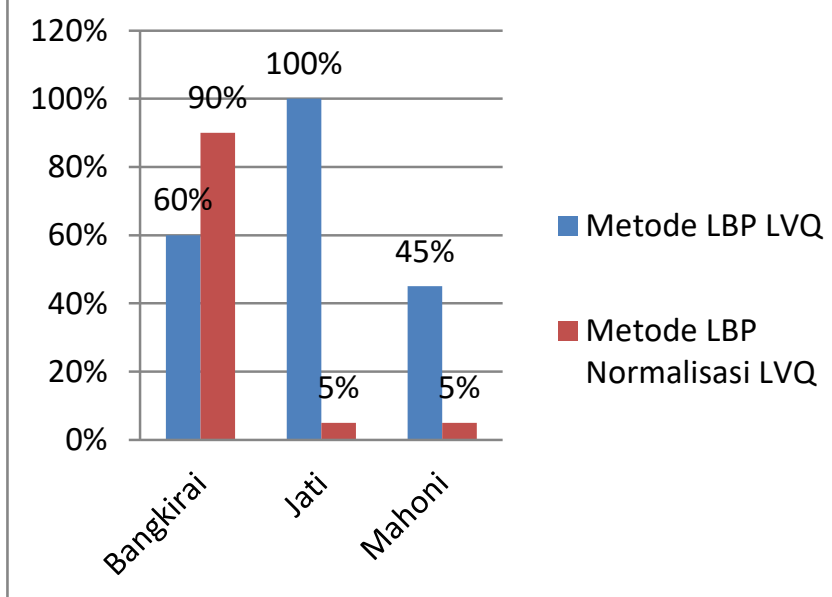

Gambar 12. Perbandingan Akurasi Sampel Kayu

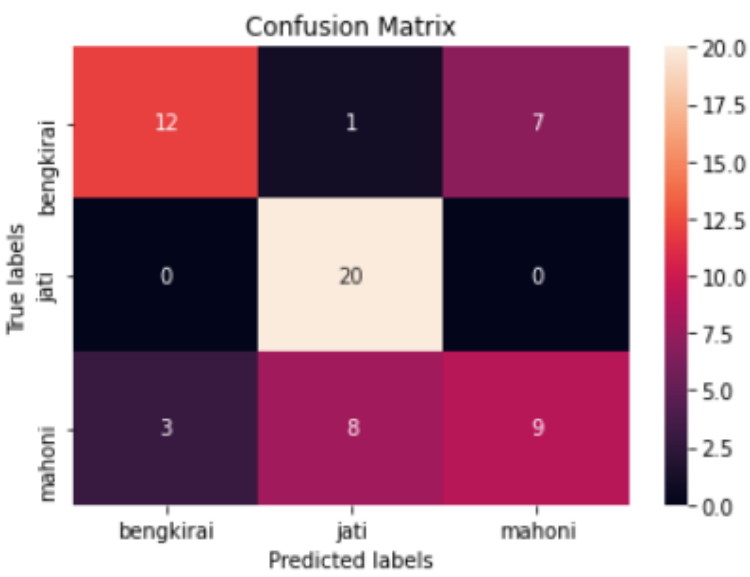

Gambar 13. Confusion Matrix Metode LBP dan LVQ 
Tabel 3. Hasil Pengujian Metode LBP LVQ dengan Confusion Matrix

\begin{tabular}{ccc}
\hline Jenis Kayu & Precision & Recall \\
\hline Bangkirai & 0,80 & 0,60 \\
Jati & 0,69 & 1,00 \\
Mahoni & 0,56 & 0,45 \\
\hline Akurasi & \multicolumn{2}{c}{$\mathbf{0 , 6 8}$} \\
\hline
\end{tabular}

Berdasarkan Tabel 2 di atas bisa dilihat bahwa kayu bangkirai mempunyai precision paling tinggi yaitu 0,80 dan recall yang paling tinggi adalah kayu jati yaitu 0,90 . Hasil pengujian identifikasi kayu menunjukkan akurasi lebih kecil jika dibandingkan dengan penelitian sebelumnya. Hal tersebut dapat dipengaruhi oleh beberapa faktor yaitu jumlah citra latih dan terdapat beberapa citra kayu memiliki pola yang hampir sama.

\section{KESIMPULAN}

Berdasarkan hasil penelitian maka dapat disimpulkan beberapa hal diantaranya: (1) Hasil pengujian citra kayu dengan metode ekstraksi LBP dan klasifikasi LVQ dengan menggunakan parameter numpoint 1 sampai 10 dan radius 1 sampai 10 didapatkan akurasi paling tinggi yaitu $68,33 \%$ pada numpoint 2 dan radius 1. (2) Berdasarkan percobaan dengan nilai numpoint 1 sampai 10 dan radius 1 sampai 100 hasilnya acak. Dapat dikatakan bahwa percobaan identifikasi kayu bangkirai, jati dan mahoni dengan menggunakan metode ekstraksi LBP dan klasifikasi LVQ tidak disarankan. (3) Ada beberapa faktor yang mempengaruhi hasil percobaan penelitian ini yaitu jumlah citra latih dan terdapat beberapa citra kayu memiliki pola yang hampir sama. Jika diamati secara visual tekstur kayu bangkirai, jati dan mahoni hampir mirip.

\section{REFERENSI}

[1] Y. I. Mandang, R. Damayanti, T. E. Komar, and S. Nurjanah, "Pedoman Identifikasi Kayu Ramin dan Kayu Mirip Ramin," ITTO Proj. PD, vol. 426, no. 06, 2008.

[2] Y. I. Mandang, S. Prawirohatmodjo, I. K. N. Pandit, and S. Danimihardja, Pedoman identifikasi jenis kayu di lapangan. Yayasan Prosea, 2002.

[3] I. Santoso, Y. Christyono, and M. Indriani, "Kinerja Pengenalan Citra Tekstur menggunakan Analisis Tekstur Metode Run Length," 2007.

[4] C. Trisyanto, "Sistem Identifikasi Kayu Ramin Berbasis Citra Menggunakan Local Binary Pattern Dan Probabilistic Neural Network," Institut Pertanian Bogor, 2012.
[5] F. N. Achsani et al., "Deteksi Adanya Cacat Pada Kayu Menggunakan Metode Local Binary Pattern Detection Of The Existence Of The Defects In Wood," vol. 2, no. 1, pp. 298-305, 2015.

[6] A. Y. Fikri and R. A. Pramunendar, "Identifikasi Jenis Kayu Menggunakan Learning Vector Quantization Berdasarkan Fitur Tekstur Gray Level Co-Occurrence Matrix," Univ. Dian Nuswantoro, pp. 1-8, 2015.

[7] E. Purwanti and P. Widiyanti, "Using learning vector quantization method for automated identification of mycobacterium tuberculosis," Indones. J. Trop. Infect. Dis., vol. 3, no. 1, pp. 26-29, 2015.

[8] S. Godara and R. Gupta, "Neural Networks for Iris Recognition: Comparisons between LVQ and Cascade Forward Back Propagation Neural network Models, Architectures and Algorithm," Neural Networks, vol. 3, no. 1, pp. 7-10, 2013.

[9] I. Afrianto, "Perbandingan Metode Jaringan Syaraf Tiruan Backpropagation Dan Learning Vector Quantization Pada Pengenalan Wajah," KOMPUTA J. Komput. dan Inform., vol. 1, no. 1, 2012.

[10] A. P. Nagare, "License plate character recognition system using neural network," Int. J. Comput. Appl., vol. 25, no. 10, pp. 36-39, 2011.

[11] M. W. Andani, "Verifikasi Tanda Tangan Menggunakan Ekstraksi Fitur LBP dan Klasifikasi LVQ," PubI. PSTI FT-UNRAM, 2020.

[12] I. Yushar, I. P. N. Purnama, Sutardi, and L. B. Aksara, "Pengenalan Wajah Berbasis Perhitungan Jarak Fitur LBP Menggunakan Euclidean, Manhattan, Chi Square Distance," Semin. Nas. APTIKOM, pp. 386-393, 2019.

[13] B. Achmad and K. Firdausy, "Teknik Pengolahan Citra Digital Menggunakan Delphi," Yogyakarta Ardi Publ., 2005.

[14] T. Ojala, M. Pietikainen, and T. Maenpaa, "Multiresolution gray-scale and rotation invariant texture classification with local binary patterns," IEEE Trans. Pattern Anal. Mach. Intell., vol. 24, no. 7, pp. 971-987, 2002, doi: 10.1109/TPAMI.2002.1017623.

[15] C. D. Suhendra and A. C. Saputra, "Penentuan Parameter Learning Rate Selama Pembelajaran Jaringan Syaraf Tiruan," vol. 14, no. 2, pp. 202-212, 2020.

[16] M. Resa, A. Yudianto, and H. Al Fatta, "Wayang dengan Algoritma Convolutional Neural Network," no. 2, pp. 182-190, 2020. 